\title{
Study on Regional Land Ecological Security Evolvement: A Case of Hangzhou*
}

\section{Shaofeng YUAN}

Department of land resources management, Zhejiang Gongshang University, Hangzhou 310018, China, Email:shaofengyuan1975@163.com

\begin{abstract}
:
Based on clarifying of related conceptions of land ecological security, this paper discusses the evaluation methods on regional land ecological security. Taking Hangzhou City in Zhejiang Province as study region, from the aspects of nature, economy, society, and according to PSR model, 18 indexes, which have significant impact on the ecological security in the region, are selected to construct the land ecological security evaluation index system. Moreover, the Analytic Hierarchy Process model is introduced to ascertain the weight of each index, and then each index's safety indicator. The land ecological security values are calculated from 2000 to 2006, and the result shows that during this period, although there is some improvement in Hangzhou City, the land ecological security is still in the grade of "Common".
\end{abstract}

Key Words: Land resources, Ecological security, Indicator system, Hangzhou

\footnotetext{
*Author: Shaofeng YUAN, 1975 , Visiting Scholar to Cambridge University, Associate Professor.

Foundation item: State Education Commission Foundation (10YJA630197); Zhejiang Province Education Department Foundation (Y200906767).
} 


\section{INTRODUCTION}

Land enological system is the carrier to all resources and environment, nevertheless along with the speedy development of economy, the deteriorated land ecology has threatened the land security, which is one of the important aspects of the nation security (Ren, 2003). In China, the acreage of land suffering for water and soil loss is 3.56 million $\mathrm{km} 2$, account for $37 \%$ of country land; the area of desertification reach to 2.62 million $\mathrm{km} 2$, it is twice of the cultivated land acreage, and it is increasing in the speed of 2,400 km2 per year ( $\mathrm{Li}, 2002)$. According to specialist's estimation, the economic loss account to 12.5 billion RMB induced by land pollution, and 54 billion RMB induced by land desertification (Zhang, 2006). In front of such austere reality, how to ensure the security of land ecological system is an important problem related to the survival and the development human beings, and it is a really necessary scientific field for us to focus on. In recent, most of the researches related to land ecological security focused on ecologically frail and sensitive regions of mountains, hills, sand, while there are less literatures paid attention to the development regions with huge population and less acreage. It is necessary to carry out land ecological security studies on development area, so as to accelerate the sustainable progress of the society. On the bases of pioneer's work, this paper choose Hangzhou City as studying region, establish land ecological security appraisal index system to assess the land ecological security state, in order to provide effective references for land ecological security research and management in Hangzhou, even in the whole China.

\section{THE IDENTIFICATION OF LAND ECOLOGICAL SECURITY APPRAISAL}

Land ecological security is a new concept, originates from the "ecological security" which arises recent years (Liang, 2005). The relative concepts, including land ecological security, regional land ecological environment security, regional land ecological security, land resources ecological security, and so on, still have not reach to uniform, but they have a basic consistent meaning. Integrating all the concepts, the concept of regional land ecological security (RLES) in this paper, is a land resources state of balanced, healthy and sustainable, without or with less threat of pollution in a certain region (Liu, 2006).

Land ecological security appraisal means an assessment to the healthy risk or damage state of land ecosystem. It is the base and core of land ecological environment security research, and is an important warrant of land ecological environment security analysis, forecast and pre-warning, land planning and construction. Its aim is to quantitatively evaluate the function of land ecological environmental system, and its influence to social economy and agricultural sustainability induced by its change (Niu, 2006; Reshmidevi, 2009; Dengiz, 2009).

\section{SAMPLING REGION}


Hangzhou located in the north of Zhejiang Province, and it is the secondary largest center city in the Yangzi River Delta. It governs 15 administrative local regions and counties, with acreage of 1,6600 km2, including $3068 \mathrm{~km} 2$ of urban area, and with total population of 6.604 million, including 4.095 million of urban population. The total GDP reaches to top 8th of China, per capita GDP overruns 10 thousand \$, total product value breaches 1000 billion RMB by 2008 . The main land types are forest land and cultivated land. The land use structure is: forest land $59.6 \%$, cultivated land $15 \%$, water area $7.66 \%$, orchard land $5.4 \%$, residential and industrial land $4.97 \%$, transportation land $0,97 \%$, other used land $0.95 \%$ and unused land $5.3 \%$. In the local urban administrative region, the land use structure is: cultivated land $37.02 \%$, forest land $19.06 \%$, water area $16.86 \%$, residential and industrial land $16 \%$, the total acreage of orchard, grass and unused land no more then $10 \%$.

On one hand, land shortage becomes the bottleneck of urban development, and on the other hand, industrialization and urbanization make the land shortage and deterioration more serious. In the process of economy growth in Hangzhou, the phenomena of using inferior to balance prior cultivated land, soil contamination, and overdevelopment and so on, not only decline the land quality and productivity, but also cast threat on the ecological system, and then deter the harmony and sustainability of regional nature, economy and society.

\section{THE REGIONAL LAND ECOLOGICAL SECURITY APPRAISAL INDEX SYSTEM}

\subsection{Indexes choosing}

Recently, the "Pressure-State-Response, PSR" concept model, proposed by OECD and UNEP, for its characteristics of easy to be understood, scientific, and feasible, are introduced to most of ecological security appraisal (Walz, 2000).

On the principles of scientific, complete, independent, comparable, feasible, data acquirable, and considering the ecological environment and characteristic of land use of Hangzhou, this paper conceives the PRR framework model and the land ecological security appraisal index system, with 18 important indexes in 3 hierarchies. The 1st hierarchy (A) is object, says land ecological security; the 2nd hierarchy (B) is factor, including land natural ecological security (the state of land resources), land economic ecological security (the pressure of land resources) and land social ecological security (social response); the 3rd hierarchy (C) is indicator, is collection of natural, economic and social indexes having significant influence to land ecological security. Hierarchy B and hierarchy A are show in Table I.

The attributes of indicators are categorized into 2 kinds, the positive and the negative. The feature of the positive indicators is that the greater the values the better the ecological situation, and the feature of the negative indicators is that the greater the values the worse the ecological situation. There are 5 negative indicators, including Acid rain rate, Acreage ratio of water and 
soil loss, Percentage of sloping cultivated land with gradients over 25 , Population density and Population growth rate, and the other 13 indicators all have the positive attribute, showed as in Table I.

TABLE I. THE INDEX SYSTEM OF LAND ECOLOGICAL SECURITY APPRAISAL

\begin{tabular}{|c|c|c|}
\hline B Factor & Attribute & C Indicator \\
\hline \multirow{6}{*}{$\begin{array}{c}\text { B1 } \\
\text { Natural } \\
\text { (State) }\end{array}$} & - & $\mathrm{C} 1$ Acid rain rate $(\%)$ \\
\hline & - & $\mathrm{C} 2$ Acreage ratio of water and soil loss $(\%)$ \\
\hline & + & $\mathrm{C} 3$ Forest coverage rate $(\%)$ \\
\hline & - & C4 Percentage of sloping cultivated land with gradients over $25(\%)$ \\
\hline & + & C5 Cultivated land rate $(\%)$ \\
\hline & + & C6 Water land rate $(\%)$ \\
\hline \multirow{7}{*}{$\begin{array}{c}\text { B2 } \\
\text { Economic } \\
\text { (Pressure) }\end{array}$} & - & C7 Population density (people/km2) \\
\hline & - & C8 Population growth rate $(\%)$ \\
\hline & + & C9 Per capita cultivated land (hm2/people) \\
\hline & + & C10 Fertilizer load per capita cultivated land $(\mathrm{kg} / \mathrm{hm} 2)$ \\
\hline & + & C11 Pesticide load per capita cultivated land $(\mathrm{kg} / \mathrm{hm} 2)$ \\
\hline & + & C12 Employment rate $(\%)$ \\
\hline & + & C13 Urbanization rate $(\%)$ \\
\hline \multirow{5}{*}{$\begin{array}{c}\text { B3 } \\
\text { Social } \\
\text { (Response) }\end{array}$} & + & C14 Agricultural mechanization $\quad(\mathrm{kw} / \mathrm{hm} 2)$ \\
\hline & + & C15 Electricity consumption per capita in rural area $(\mathrm{kwh} / \mathrm{hm} 2)$ \\
\hline & + & C16 Per capita GDP (RMB) \\
\hline & + & C17 Rural per capita net income (RMB) \\
\hline & + & C18 Percentage of Tertiary Industry as GDP (\%) \\
\hline
\end{tabular}

\subsection{Wight of the appraisal index system}

In the process of appraisal, the weights to every index are all-important for the matching between the results and the factual situation. In 1970s, an American management scientist named T.L. Satty designed the Analytical Hierarchy Process (AHP) model as a decision making aid. AHP is especially suitable for complex decisions which involve the comparison of decision elements which are difficult to quantify. It is based on the assumption that when faced with a complex decision the natural human reaction is to cluster the decision elements according to their common characteristics. It involves building a hierarchy (Ranking) of decision elements and then making comparisons between each possible pair in each cluster (as a matrix). This gives a weighting for each element within a cluster (or level of the hierarchy) and also a consistency ratio (useful for checking the consistency of the data). For the characteristics of preciseness and easy to operate, it is introduced in this study, the detailed 
steps and methods see literatures (Zhang, 2003; Li,1989). The AHP analysis results shows in Table II.

According to the AHP result, C2 (Acreage ratio of water and soil loss) plays the most important role, and account for $18.94 \%$ of the total weight, this phenomenon accords with hilly and mountainous relief in Hangzhou. The secondary important index is C7 (Population density), weighted 11.69\%. Nevertheless, C3 (Forest coverage rate) and C4 (Percentage of sloping cultivated land with gradients over $25^{\circ}$ ) are both important, and their weights both reach to $10.24 \%$. As a whole, natural factor is the most key factor, it account for half of the total weight, followed by economic factor and social factor. The result is true of actual instance.

TABLE II. THE RESUlt OF INDEX SYSTEM ANALYZED BY AHP

\begin{tabular}{|l|l|l|l|c|}
\hline \multirow{2}{*}{ Hierarchy C } & \multicolumn{3}{|c|}{ B1 } & \multicolumn{2}{c|}{ B2 } & \multirow{2}{*}{ B3 } & $\begin{array}{c}\text { Combinatorial } \\
\text { weight }\end{array}$ \\
\cline { 2 - 5 } & 0.5396 & 0.2970 & 0.1634 & 0.0677 \\
\hline C1 & 0.1254 & 0 & 0 & 0.1894 \\
\hline C2 & 0.3510 & 0 & 0 & 0.1024 \\
\hline C3 & 0.1898 & 0 & 0 & 0.1024 \\
\hline C4 & 0.1898 & 0 & 0 & 0.0479 \\
\hline C5 & 0.0887 & 0 & 0 & 0.0298 \\
\hline C6 & 0.0553 & 0 & 0 & 0.1169 \\
\hline C7 & 0 & 0.3937 & 0 & 0.0205 \\
\hline C8 & 0 & 0.0690 & 0 & 0.0776 \\
\hline C9 & 0 & 0.2614 & 0 & 0.0097 \\
\hline C10 & 0 & 0.0325 & 0 & 0.0097 \\
\hline C11 & 0 & 0.0325 & 0 & 0.0205 \\
\hline C12 & 0 & 0.0690 & 0 & 0.0421 \\
\hline C13 & 0 & 0.1419 & 0 & 0.0100 \\
\hline C14 & 0 & 0 & 0.0613 & 0.0100 \\
\hline C15 & 0 & 0 & 0.0613 & 0.0551 \\
\hline C16 & 0 & 0 & 0.3370 & 0.0332 \\
\hline C17 & 0 & 0 & 0.2034 & 0.0551 \\
\hline C18 & 0 & 0 & 0.3370 & \\
\hline
\end{tabular}

\subsection{The security standards of the indexes}

On the bases of literature analysis, the standard values of land ecological security are ascertained according to the characteristics and states of each index and that of land ecology in Hangzhou. Acid rain rate (C1) is a negative index for land ecological security, the unsafe standard of $100 \%$ acid rain of European Union is adopted in this study; Percentage of sloping 
cultivated land with gradients over $25^{\circ}(\mathrm{C} 4)$ is also a negative index, and the standard adopts the Chinese national unsafe standard of 4.5\%; Another negative index C7 (Population density) standard adopts the average value of Zhejiang Province 128.78 people/km2. For other indexes standards, internationally recognized values, the average values of world, the average values of China, or the average values of Zhejiang Province are adopted respectively, according to the factual situation of Hangzhou region. For example, to the standard of index C16 (Per capita GDP), there are quite differentials among the average values of world, China and Zhejing Province, the internationally recognized value of $3000 \$$ is adopted as the standard, multiplied by the average exchange rate during 2000-2009, amount to 24381 RMB.

TABLE III. THE STANDARDS \& MEASURED VALUES OF LAND ECOLOGICAL SECURITY (2000 2009)

\begin{tabular}{|c|c|c|c|c|c|c|c|c|c|c|c|c|}
\hline \multirow{2}{*}{ Index } & \multicolumn{2}{|c|}{ Standards } & \multicolumn{10}{|c|}{ Measured values $X$} \\
\hline & Unsafe & Safe & 2000 & 2001 & 2002 & 2003 & 2004 & 2005 & 2006 & 2007 & 2008 & 2009 \\
\hline C1 & 100 & - & 77.4 & 82.7 & 73.6 & 69.0 & 75.07 & 77.6 & 79.8 & 80.4 & 81.8 & 83.1 \\
\hline C2 & 38 & - & 17.39 & 16.36 & 15.58 & 13.13 & 12.77 & 12.43 & 11.99 & 11.71 & 12.35 & 11.84 \\
\hline C3 & - & 54.10 & 61.9 & 62.3 & 62.4 & 62.8 & 62.8 & 62.8 & 62.8 & 63.3 & 63.7 & 64.2 \\
\hline $\mathrm{C} 4$ & 4.5 & - & 5.99 & 6.01 & 6.01 & 6.03 & 6.03 & 6.03 & 6.03 & 6.03 & 6.03 & 6.03 \\
\hline C5 & - & 30 & 16 & 15.6 & 15.4 & 15.3 & 15.3 & 15.3 & 15.2 & 15.2 & 15.1 & 15.2 \\
\hline C6 & - & 4 & 3.33 & 3.67 & 3.89 & 3.92 & 3.97 & 3.97 & 3.99 & 3.96 & 4.01 & 4.02 \\
\hline C7 & - & 128.78 & 375 & 379 & 384 & 387 & 393 & 414 & 401 & 405.1 & 407.9 & 412 \\
\hline C8 & 5.87 & - & 3.62 & 3.6 & 2.92 & 2.72 & 3.99 & 1.41 & 1.19 & 3.36 & 2.77 & 3.42 \\
\hline C9 & - & 0.08 & 0.031 & 0.03 & 0.03 & 0.028 & 0.028 & 0.028 & 0.027 & 0.027 & 0.026 & 0.026 \\
\hline C10 & 4.19 & - & 57.52 & 62.96 & 66.73 & 66.96 & 67.33 & 67.81 & 68.49 & 68.93 & 69.41 & 69.83 \\
\hline C11 & 0.13 & - & 8.365 & 9.166 & 8.779 & 8.911 & 9.457 & 9.337 & 9.684 & 9.532 & 9.72 & 9.689 \\
\hline C12 & - & 99.30 & 98.78 & 98.91 & 99.34 & 99.58 & 98.87 & 99.53 & 99.75 & 79.29 & 84.01 & 87.4 \\
\hline C13 & - & 56.61 & 58.3 & 59.89 & 60.97 & 61.54 & 62.06 & 63.83 & 64.11 & 64.39 & 64.84 & 65.21 \\
\hline C14 & 20 & - & 24 & 24 & 24 & 25 & 25 & 26 & 26 & 26 & 26 & 27 \\
\hline C15 & - & 1800 & 2327 & 2394 & 2475 & 2568 & 2642 & 2731 & 2828 & 2916 & 2993 & 3032 \\
\hline C16 & - & 24381 & 22342 & 25074 & 28150 & 32819 & 39293 & 44853 & 51878 & 61315 & 70948 & 74761 \\
\hline C17 & - & 2622 & 4496 & 4898 & 5242 & 5740 & 6382 & 7655 & 8515 & 9546 & 10692 & 11822 \\
\hline C18 & - & 66.3 & 41.2 & 42.3 & 42.8 & 42.1 & 43 & 44.1 & 45.1 & 45.8 & 46.7 & 49.3 \\
\hline
\end{tabular}

Note: The data of land usage cited from Statistics of Land Record and Land use change survey (2001-2010) of Hangzhou Land \& Resource Bureau. The social and economic data cited from Hangzhou Yearbook, Zhejiang Yearbook and Chinese City Yearbook (2001-2010). “+” means positive index, “-” means negative index. The exchange rate is 8.1269 , calculated from 84 months of data during 2000-2009, which collected from The People's Bank of China (central bank) website.

\section{LAND ECOLOGICAL SECURITY ASSESSMENT AND ANALYSIS}

\subsection{The security value of indexes}


Referring to relative literatures (Bouma, 2002; Dumanskia, 2002; Quan, 2007), the method of index security values calculation is shown as follow: (1) Positive indexes have the characteristic of the greater the value the safer the land ecologically. Taking "safe value" as standard, and the measured value (x) $\geq$ standard value (s), then the index value should be 1 ; Otherwise the index value should be $\mathrm{x} / \mathrm{s}$. When taking "unsafe value" as standard, and $\mathrm{x} \leq \mathrm{s}$, then the index value should be 0 ; Otherwise the index value should be $1-\mathrm{s} / \mathrm{x}$. (2) Negative indexes have the characteristic of the greater the value the more unsafe the land ecologically. Taking "safe value" as standard, and $x \leq s$, then the index value should be 1 ; otherwise the index value should be $\mathrm{x} / \mathrm{s}$. When taking "unsafe value" as standard, and $\mathrm{x} \geq \mathrm{s}$, then the index value should be 0 ; otherwise the index value should be $1-\mathrm{s} / \mathrm{x}$. The land ecological security indexes values of Hangzhou during 2000-2009 are showed as in Table IV.

TABLE IV. The LAND ECOLOGICAL SECURITY INDEXES VALUES

\begin{tabular}{|c|c|c|c|c|c|c|c|c|c|c|}
\hline \multirow{2}{*}{ Index } & \multicolumn{8}{|c|}{ Land ecological security index value P(Ci) } \\
\cline { 2 - 12 } & $\mathbf{2 0 0 0}$ & $\mathbf{2 0 0 1}$ & $\mathbf{2 0 0 2}$ & $\mathbf{2 0 0 3}$ & $\mathbf{2 0 0 4}$ & $\mathbf{2 0 0 5}$ & $\mathbf{2 0 0 6}$ & $\mathbf{2 0 0 7}$ & $\mathbf{2 0 0 8}$ & $\mathbf{2 0 0 9}$ \\
\hline C1 & 0.2260 & 0.1730 & 0.2640 & 0.3100 & 0.2493 & 0.2240 & 0.2020 & 0.1960 & 0.1820 & 0.1690 \\
\hline C2 & 0.5424 & 0.5695 & 0.5900 & 0.6545 & 0.6639 & 0.6729 & 0.6845 & 0.6918 & 0.6750 & 0.6884 \\
\hline C3 & 1.0000 & 1.0000 & 1.0000 & 1.0000 & 1.0000 & 1.0000 & 1.0000 & 1.0000 & 1.0000 & 1.0000 \\
\hline C4 & 0.0000 & 0.0000 & 0.0000 & 0.0000 & 0.0000 & 0.0000 & 0.0000 & 0.0000 & 0.0000 & 0.0000 \\
\hline C5 & 0.5333 & 0.5200 & 0.5133 & 0.5100 & 0.5100 & 0.5100 & 0.5067 & 0.5067 & 0.5033 & 0.5067 \\
\hline C6 & 0.8325 & 0.9175 & 0.9725 & 0.9800 & 0.9925 & 0.9925 & 0.9975 & 0.9900 & 1.0000 & 1.0000 \\
\hline C7 & 0.3434 & 0.3398 & 0.3354 & 0.3328 & 0.3277 & 0.3111 & 0.3211 & 0.3179 & 0.3157 & 0.3126 \\
\hline C8 & 0.3833 & 0.3867 & 0.4974 & 0.4974 & 0.3203 & 0.7598 & 0.7973 & 0.4276 & 0.5281 & 0.4174 \\
\hline C9 & 0.3875 & 0.3750 & 0.3750 & 0.3500 & 0.3500 & 0.3500 & 0.3375 & 0.3375 & 0.3250 & 0.3250 \\
\hline C10 & 0.9272 & 0.9334 & 0.9372 & 0.9374 & 0.9378 & 0.9382 & 0.9388 & 0.9392 & 0.9396 & 0.9400 \\
\hline C11 & 0.9844 & 0.9858 & 0.9852 & 0.9854 & 0.9863 & 0.9861 & 0.9866 & 0.9864 & 0.9866 & 0.9866 \\
\hline C12 & 1.0000 & 1.0000 & 1.0000 & 1.0000 & 1.0000 & 1.0000 & 1.0000 & 0.7985 & 0.8460 & 0.8802 \\
\hline C13 & 1.0000 & 1.0000 & 1.0000 & 1.0000 & 1.0000 & 1.0000 & 1.0000 & 1.0000 & 1.0000 & 1.0000 \\
\hline C14 & 0.1667 & 0.1667 & 0.1667 & 0.2000 & 0.2000 & 0.2308 & 0.2308 & 0.2308 & 0.2308 & 0.2591 \\
\hline C15 & 1.0000 & 1.0000 & 1.0000 & 1.0000 & 1.0000 & 1.0000 & 1.0000 & 1.0000 & 1.0000 & 1.0000 \\
\hline C16 & 0.9166 & 1.0000 & 1.0000 & 1.0000 & 1.0000 & 1.0000 & 1.0000 & 1.0000 & 1.0000 & 1.0000 \\
\hline C17 & 1.0000 & 1.0000 & 1.0000 & 1.0000 & 1.0000 & 1.0000 & 1.0000 & 1.0000 & 1.0000 & 1.0000 \\
\hline C18 & 0.6214 & 0.6380 & 0.6456 & 0.6350 & 0.6486 & 0.6652 & 0.6802 & 0.6908 & 0.7044 & 0.7436 \\
\hline
\end{tabular}

\subsection{The factor security scores calculation}

The factor security scores are measured by integrated graded approach, hierarchy by hierarchy (see Table V).

The calculation formulas are shown as below: 
$S=P\left(C_{i}\right) \cdot w_{i}$

$V=\sum_{i=1}^{n} P(C i) \cdot w_{i}$

Where, $\mathrm{S}$ denotes the index security value; $\mathrm{P}(\mathrm{Ci})$ is the factor security value; $\mathrm{V}$ is integrated factor security score; $\mathrm{Wi}$ is the weight of index; $\mathrm{n}$ denotes the total number of indexes.

TABLE V. THE SCORES OF LAND ECOLOGICAL SECURITY (2000-2009)

\begin{tabular}{|c|c|c|c|c|}
\hline Year & Natural & Economic & Social & Integrated \\
\hline $\mathbf{2 0 0 0}$ & 0.2708 & 0.1592 & 0.1296 & 0.5596 \\
\hline $\mathbf{2 0 0 1}$ & 0.2742 & 0.158 & 0.1351 & 0.5673 \\
\hline $\mathbf{2 0 0 2}$ & 0.2856 & 0.1598 & 0.1355 & 0.5809 \\
\hline $\mathbf{2 0 0 3}$ & 0.301 & 0.1575 & 0.1353 & 0.5938 \\
\hline $\mathbf{2 0 0 4}$ & 0.299 & 0.1533 & 0.136 & 0.5883 \\
\hline $\mathbf{2 0 0 5}$ & 0.299 & 0.1604 & 0.1373 & 0.5967 \\
\hline $\mathbf{2 0 0 6}$ & 0.2997 & 0.1613 & 0.1381 & 0.5991 \\
\hline $\mathbf{2 0 0 7}$ & 0.3005 & 0.1493 & 0.1387 & 0.5884 \\
\hline $\mathbf{2 0 0 8}$ & 0.2965 & 0.1511 & 0.1394 & 0.5869 \\
\hline $\mathbf{2 0 0 9}$ & 0.2983 & 0.1491 & 0.1419 & 0.5893 \\
\hline
\end{tabular}

\subsection{The adjudication criteria for land ecological security grade}

Referring to literatures and the actual conditions of the studying region (Liu,2004), the state of land ecological is sorted to 5 grades (see Table VI). The higher the score is, the safer the land ecological security is, and vice versa.

TABLE VI THE ADJUDICATION CRITERIA FOR REGIONAL LAND ECOLOGICAL SECURITY GRADE

\begin{tabular}{|c|c|c|l|}
\hline $\begin{array}{c}\text { Threshold } \\
\text { value }\end{array}$ & Grade & State & \multicolumn{1}{c|}{ Characteristics } \\
\hline$<0.2$ & I & $\begin{array}{l}\text { Extremely } \\
\text { bad }\end{array}$ & $\begin{array}{l}\text { The land ecosystem service function nearly collapsed, and it } \\
\text { is hard to reverse: The ecological environment is seriously } \\
\text { damaged, the structure is fragmentary, the functions lost, } \\
\text { recovery and reestablishment are difficult, and the problems } \\
\text { are very serious, and often evolve into ecological disasters. }\end{array}$ \\
\hline $0.2 \sim 0.4$ & II & Bad & $\begin{array}{l}\text { The land ecosystem service function is degraded seriously: } \\
\text { the ecological environment is damaged relatively; the } \\
\text { structure is destroyed badly; the functions degraded and are } \\
\text { not integrated, and are difficult to recover for the } \\
\text { disturbance from outside; the problems are relatively }\end{array}$ \\
\hline
\end{tabular}




\begin{tabular}{|l|l|l|l|}
\hline $0.4 \sim 0.6$ & III & Common & $\begin{array}{l}\text { serious, and with relative amount of ecological disasters. } \\
\text { Che land ecosystem service function is already degraded: } \\
\text { the ecological environment is damaged to some extent; the } \\
\text { structure has changed; the basic functions can be sustained, } \\
\text { and apt to be worse with disturbance; the problems are } \\
\text { obvious, and with ecological disasters happened sometimes. }\end{array}$ \\
\hline $0.6 \sim 0.8$ & IV & Good & $\begin{array}{l}\text { The land ecosystem service function is relatively perfect: } \\
\text { the ecological environment suffers from damage rarely; the } \\
\text { structure still keeps intact; the functions still fine, and } \\
\text { usually can recover from disturbance; the ecological } \\
\text { problems are unremarkable, accompanied with less } \\
\text { ecological disasters. }\end{array}$ \\
\hline$\geq 0.8$ & V & Ideal & $\begin{array}{l}\text { The land ecosystem service function is essentially perfect: } \\
\text { the ecological environment is undamaged essentially; the } \\
\text { structure is intact, and with powerful functions and powerful } \\
\text { regeneration capability; the ecological problems are } \\
\text { unremarkable, with ecological disasters happened seldom or } \\
\text { never. }\end{array}$ \\
\hline
\end{tabular}

\section{DISCUSSION}

During the period of 2000-2009, the land ecological security integrated scores shows an increasing tendency, it means the state of land ecological security in Hangzhou is becoming better and better, but the land ecological security states, in these years, are still located in "Common" level. The land ecosystem service function is already degraded; the ecological environment is damaged to some extent; the structure has changed; the basic functions can be sustained, and apt to be worse with disturbance; the problems are obvious, and with ecological disasters happened sometimes.

(1) The land natural ecological security system has ameliorated obviously. As a whole, the natural factors have the most significant influence to the appraisal results, the trend of the land ecological security scores is under the influence of the natural factor values of land ecological security during the period of 2000-2009. To reduce the acid rain rate, Hangzhou Council has issued a bunch of policies, including The Acid Rain and Sulfur Dioxide Pollution Control Planning. These policies have improved the land quality to some extent. In the aspect of water and soil loss control, Hangzhou Council adjusts measure to local conditions and pays equal attention to the scientific \& technological measures and management measures, and proposes the prevention and remedy approaches. For such efforts, the "Acreage ratio of water and soil loss" declined from $17.39 \%$ in 2000 to $11.84 \%$ in 2009 . At the same time, the land use efficiency is elevated effectively by means of land using structure adjustment. For example, 
different patterns of land usage are developed, under the precondition of assuring the cultivated land acreage, especially, the Forest City construction carried out forcefully by Hangzhou government in recent years. At present, the index Forest Coverage Rate exceeds 64\%, ranks 1st of the sub-provincial cities in China. The total green land acreage reaches to $129.7 \mathrm{~km} 2$, and Urban Park Green Land per capita reaches to $14.1 \mathrm{~m} 2$, both of them rank among the best of the kin cities.

(2) The pressure to land economic ecological security system mainly comes from population growth. Although the population growth speed slows down during the appraisal period, it is still increasing. For the speedy growth of population, a large amount of land is occupied by construction, and the human-land conflict is outstanding, there is a large per capita cultivated land gap between Hangzhou and national average. The abuse of fertilizer and pesticide induces a series of soil pollution, with secluded and latent natures, and threatens the health of human beings. Moreover, socioeconomic factors also throw pressure to land ecosystem, although the unfaltering increase of urbanization rate and employment rate eases the pressure of land ecological environment in rural region, with large amount of labor swarmed into urban, the urban land ecosystem still faces ebb and flow menace.

(3) The land social ecological security system adopts positive human environmental response mechanism. To response the land resources ecological pressure, in July 2003, Hangzhou government conceived an ecological city construction plan, which aims to complete the ecological construction in urban region before 2010, and complete the ecological construction in whole city before 2015. At the same time, Hangzhou Ecological Zone Concept Planning was revised and ameliorated. During the period of 2000-2009, "Agricultural mechanization" and "Electricity consumption per capita in rural area" in Hangzhou keep ascendant trend, and "Electricity consumption per capita in rural area" is higher than that of national average level $1800 \mathrm{kwh} / \mathrm{hm} 2$ all the time. This condition has increased the food production per capita cultivated land, and has relieved the pressure to cultivated land resources to some extent. "Per capita GDP" and "rural net income" keep increasing year after year, and this phenomenon creates more guarantees for land ecological environment security in the aspects of economy, science and technology. Simultaneously, the government positively promotes the upgrading of the industrial structure, vigorously develops tertiary industry, and encourages the high and new technology industries, which with technical innovation, less land occupation, less pollution, less resources consumption, high science $\&$ technology, and high value-added. This policy is the keystone and direction of the industrial structure upgrading, and it relieves the confliction between "industrialization-oriented city" and "environment-oriented city", on one hand, saves the land for the city development, one the other hand, improves ecological environment.

\section{ACKNOWLEDGMENT}


The author gratefully acknowledge to my students and colleagues in University of Cambridge for data collection and discussions and commitments. I would also like to recognize the State Education Commission Foundation (project 10YJA630197), Zhejiang Province Education Department Foundation (project Y200906767), for financial support.

\section{REFERENCES}

[1] Bouma, J., 2002, Land quality indicators of sustainable land management across scales, Agriculture, Ecosystems and Environment, 88(2), 129-136.

[2] Dengiz ,O., and Baskan, O., 2009, Land quality assessment and sustainable land use in Salt Lake (Tuz Glü) speciallyprotected area, Environmental Monitoring and Assessment, 148(1), 233-243.

[3] Dumanskia, J., and Pieri, C., 2002, Land quality indicators: Research plan, Agriculture, Ecosystems and Environment, 81(2),93-102.

[4] Li, X., 1989, Fundamental and Methods of Land Resources Evaluation, Changsha:Hunan Science and Technology Press.

[5] Li, Z., and Liu, X., 2002, The ecological security problems in China, Ecological Economy, (8), 10-13,

[6] Liang, L., et al., 2005, Study on the construction of land-ecological safety system, Journal of Yunnan Agricultural University, 20(6), 829-834.

[7] Liu, Y., et al., 2004, Evaluation on ecological security of regional land resources: a case study of Jiaxing City, Zhejiang Province, Resources Science, 26(3), 69-75.

[8] Niu, H., 2006, The Relative Change in the Quantity of Cultivated Land Based on Niche Theory:A Case Study of Jiaozuo City, Areal Research and Development, 25(12), 112-117.

[9] Quan, B., et al., 2007, Land suitability assessment and land use change in Fujian Province, China, Pedosphere, 17(4), 493-504.

[10] Ren, Z., et al., 2003, Land Use Change and Ecological Safety Evaluation, Beijing: Science Press.

[11] Reshmidevi, T., et al., 2009, A GIS integrated fuzzy rule2based inference system for land suitability evaluation in agricultural watersheds, Agricultural Systems, 101(1), 101-109.

[12] Walz, R., 2000, Development of Environment indicators Systems: Experience from Germany, Environment Management, 25(6), 613-623.

[13] Zhang, H., and Liu, L., 2006, Main Progress and Prospects of Land Resource Ecological Security Research, Progress in Geography, 25(5), 77-85.

[14] Zhang, H., et al., 2003, Natural productivity evaluation of cultivated land based on GIS and RS data in Houhu Farm of Jianghan Plain, Transactions of the Chinese Society of Agricultural Engineering, 19(2), 219-223. 